\title{
LITERATURE
}

$\infty$

Merritt Moseley

University of North Carolina at Asheville

moseley@unca.edu

\section{Donald Trump and the American Literary Tradition}

\begin{abstract}
Though in many ways the most unusual US president ever elected, both in experience and in character, Donald Trump is not entirely sui generis. This article strives to show that in some respects he is in the American tradition, as evidenced by his continuity with some classic American literary works. Characteristics which Trump shares with the American literary tradition include religiosity; egalitarianism, and its corollaries including anti-expertise, braggadocio, self-assurance and self-reliance; insularity and xenophobia; and American exceptionalism.
\end{abstract}

Key words: Trump; American literature; egalitarianism; xenophobia; braggadocio; self-assurance; Transcendentalism

When Donald J. Trump was elected President of the United States in November 2016, millions of people found it incomprehensible. Here was a president-elect unlike any previous successful candidate for that office. He had never held elective office (compare state governors like Reagan or Clinton, senators like Obama, vice-presidents like Nixon or Truman). Unlike previous presidents elected after leading armies to victory (Washington, Grant, Eisenhower), Trump had quite ostentatiously avoided military service. Eschewing the customary "just folks" stance of candidates who minimize their wealth, particularly if it is inherited, Trump boasted, probably exaggerated, how rich he is. Many Americans still do not understand the Trump phenomenon. But it is worth looking at his relationship to the nation's cultural history in order to reject the notion that Trump is sui generis, that he is a complete outlier in the American tradition. It is worth considering, that is, some of the ways he is connected to the traditional American ethos, particularly as it is embodied in the American literary tradition. 
There is surely nothing conscious about this on the President's part, and given what is known about his unwillingness to read, there's no likelihood that he is familiar with the classic texts of American literature. But he is in the American grain, in several ways I shall try to demonstrate.

Among the characteristics of American culture traceable through its literature, these are the ones that are most relevant to Donald Trump:

\section{Religiosity}

The United States is a country that, despite being officially free from state religion, places enormous importance on religion, which in practical terms really means on Christianity. President Trump pays sufficient acknowledgement to this importance to be perceived as a Christian. This doesn't require much theology. Addressing the evangelistic Christian college Liberty University, candidate Trump gave this heartfelt and thoughtful testimony:

"Two Corinthians 3:17, that's the whole ballgame. ... Is that the one you like?" (Milbank)

The Trump administration has enthusiastic support from millions of Christians, particularly of the evangelistic sort. But the job of being the premier Christian has been handed over to Vice President Mike Pence. He identifies as an evangelistic Catholic, by which he seems to mean that, having been raised in the Catholic faith, he is for all practical purposes a conservative Protestant. Mike Pence is the chief link to the Calvinists who were important in the early years of America, with their gloomy conviction of total depravity. H. L. Mencken's definition of a puritan as someone who is afraid that somewhere, someone is having a good time seems relevant to Pence's religious stance. One result of this is that he has famously adopted a rule that he will not have dinner alone with any woman other than his wife. Presumably such a freedom would unleash his innate depravity.

In important ways, Trump and Pence embody the long-standing tension in American life between Puritanism and hedonism. Despite a casual pretense of religiosity necessary for election, Donald Trump's whole life has been dedicated to the pleasures of the flesh. He is a hedonist, even a voluptuary. Pence is a Puritan.

In Nathaniel Hawthorne's short story of 1832, "The Maypole of Merry Mount," he dramatized this conflict in a story of two bands of settlers in $17^{\text {th }}$ century Massachusetts, the revelers of Merry Mount, who spent their lives in dancing and festivity, and the stern Puritans of a nearby settlement. Of them, Hawthorne writes, "When they met in conclave, it was never to keep up the old English mirth, but to hear sermons three hours long, or to proclaim bounties on the heads of wolves and the scalps of Indians. Their festivals were fast days, and their chief pastime the singing of psalms. Woe to the youth or maiden who did but dream of a dance!" (39). He refers the whipping post as the "Puritan May- 
pole" (39), and declares that "jollity and gloom were contending for an empire" (34). In Hawthorne's story, gloom, austerity and intolerance win out, as they have through much of American history and, insofar as President Trump has to pretend to concur with his vice president, no matter how unconvincingly, win out today.

\section{Egalitarianism and its corollaries}

One of the founding ideas of American history and culture is equality. The Declaration of Independence, the document that declared the US free from the British crown, proclaims: "We hold these truths to be self-evident, that all men are created equal..." Of course the sentiment must be immediately qualified by acknowledging the many exceptions. There was no inclination to consider women equal to men, and not only were African-American slaves denied all political rights, they were only counted as $3 / 5$ of a person in early censuses, in determining the division of political representation among the states. Native Americans were similarly ignored.

Nevertheless, it is a noble sentiment, to which almost 250 years of change and reform have allowed the nation to approach more closely. There are still controversies over equality of opportunity vs. equality of results, and so on. But I'm most interested in some of the consequences in American life of the ways this egalitarianism has been interpreted.

American egalitarianism does not always mean acknowledging the equal status and claims of other people; it's usually in the first person. The shorthand version is "I am as good as anybody else."

\section{Anti-expertise}

One result is the mistrust of experts. If I am as good as any other man, why should I listen to a "so-called expert"? (The use of the phrase "so-called expert" is an infallible tipoff of this attitude.)

As far back as 1839, Alexis de Tocqueville, a French observer and author of the book Democracy in America, wrote of "the theory of equality applied to intellects. This doctrine attacks the pride of man in its last asylum: so the minority accepts it only with difficulty; it habituates itself to it only in the long term" (236). More recently, a political scientist who has taught at Harvard, Tom Nichols, has published a book called The Death of Expertise. Nichols insists that "skepticism toward intellectual authority" (Gibson) is a historic fact, deeply engrained in the American character, but he believes it has become more serious. Americans now, Nichols has found, "actively resisted facts that might alter their preexisting beliefs. They insisted that all opinions, however uninformed, be treated as equally serious. And they rejected professional know-how, he says, with such anger" (Gibson). In his book Nichols assigns the blame, significantly, to "misguided egalitarianism run amok" (Gibson). 
How does this apply to Donald Trump? The book could almost be about Donald Trump. Among his statements that indicate his contempt for real expertise:

\author{
"You know, I've always wanted to say this-I've never said this before with all the talking \\ we all do-all of these experts, 'Oh we need an expert_-' The experts are terrible," he de- \\ clared. "Look at the mess we're in with all these experts that we have." (Gass) \\ "I know more about renewables than any human being on Earth." ("Trump Explains...") \\ "I think nobody knows more about taxes than I do, maybe in the history of the world. Nobody \\ knows more about taxes." ("Trump says...”) \\ "Nobody knows more about trade than me." (Hains) \\ "There's nobody bigger or better at the military than I am." (Blake)
}

"I know more about ISIS [the Islamic State militant group] than the generals do. Believe me." (Johnson)

"There is nobody who understands the horror of nuclear more than me." ("Nobody" on youtube)

As Nichols wrote in the Washington Post, "He vowed to push the eggheads out of the way - not because they are wrong, but because they are eggheads, and nobody likes eggheads."

Admittedly, as Nichols writes, experts sometimes seem to lack empathy for non-experts:

This is why the attack on experts appeals both to Trump and his voters: It scratches a deep itch of resentment that has nothing to do with intelligent policy and everything to do with feeling ignored by the people who have to make things work every day. In the same way that the president fulminates at being told that his ideas might be flawed or wrong, a fair number of Americans now bristle when told that they have to do anything they don't like: vaccinate their children, eat a healthy diet, put down their phones while driving. None of this is really about steel imports or fortified borders or Muslim travelers; it is about regaining a sense of empowerment. (Nichols)

Pay attention to the form of some of the president's assertions. For instance, "There is nobody who understands the horror of nuclear more than me." That is a silly thing to say, particularly while there are still people living in Hiroshima and Nagasaki who have firsthand experience of "the horror of nuclear," but it is a case of misguided egalitarianism, isn't it? It is another version of "I'm as good as anybody else." But then there is "I know more about renewables than any human being on Earth." Statements of equality always threaten to shade over into assertions of superiority. That is, "there is nobody better than 
me" often quickly becomes, "but there are a great many persons worse than me." It is admittedly rare to find someone who believes that "every single human being on earth is inferior to me," but, as we have seen, Donald Trump is a rare sort of man.

Donald Trump told an interviewer asking about his religion that he has never asked God for forgiveness (Boorstein), apparently never having done anything for which he needed to be forgiven. The same approach applies to his observations about American history. Perhaps he thinks he knows as much about that history as the so-called experts. Here are two well-known examples:

At a Black History Month event, he observed that "Frederick Douglass is an example of somebody who's done an amazing job and is getting recognized more and more, I notice" (Wootson). Frederick Douglass, the famous abolitionist and autobiographer, died in 1895 .

President Trump said President Andrew Jackson was "really angry" at "what was happening with regard to the Civil War," though Jackson had been dead for 16 years when the Civil War began; and he claimed "people don't ask the question, but why was there the Civil War?" (Lemire). This question has of course been asked over and over again in the past century and a half, producing a library full of books on the causes of the Civil War - but then, they were written mostly by so-called experts.

\section{Braggadocio}

The statement - to take an example at random- that "I am the least racist person that you have ever met" is not so much an example of classic American anti-expertise as it is of classic American boasting. Donald Trump has raised celebrating himself to a level previously unknown in the American presidency. But this is also in the American grain.

It can be found in what was called "southwestern humor"- that is the rugged humor of the backwoods in states like Tennessee, Georgia, or Missouri, the background to writers like Mark Twain. The following example is unusual because it isn't from a work of fiction. The speaker is Davy Crockett, a semi-legendary American, from Tennessee, who died at the battle of the Alamo in the war between the Texas republic and Mexico. But he was actually a member of the United States Congress, and here is one of the speeches he is reported to have delivered on the floor of the House of Representatives:

I say, Mr. Speaker; I've had a speech in soak this six months, and it has swelled me like a drowned horse; if I don't deliver it I shall burst and smash the windows. The gentleman from Massachusetts [Mr. Everett] talks of summing up the merits of the question, but I'll sum up my own. In one word I'm a screamer, and have got the roughest racking horse, the prettiest sister, the surest rifle and the ugliest dog in the district. I'm a leetle the savagest crittur you ever did see. My father can whip any man in Kentucky, and I can lick my father. I can outspeak any man on this floor, and give him two hours start. I can run faster, dive deeper, stay longer under, and come out drier, than any chap this side of the big Swamp. I can outlook a panther and outstare a flash of lightning, tote a steamboat on my back and play at rough 
and tumble with a lion, and an occasional kick from a zebra. To sum up all in one word, I'm a horse. (Fee and Webb 278).

A more purely literary illustration of the American immodesty comes from Walt Whitman's "Song of Myself," first published in 1855. Here are a few of its lines:

*I celebrate myself... (line 1)

*And I know I am solid and sound,

To me the converging objects of the universe perpetually flow,

All are written to me, and I must get what the writing means.

And I know I am deathless,

I know this orbit of mine cannot be swept by a carpenter's compass,

I know I shall not pass like a child's carlacue cut with a burnt stick at night. (lines 403-408)

*I know I am august,

I do not trouble my spirit to vindicate itself or be understood,

I see that the elementary laws never apologize,

I reckon I behave no prouder than the level I plant my house by, after all. (lines 409-412)

*Divine am I inside and out, and I make holy whatever I touch or am touched from,

The scent of these arm-pits is aroma finer than prayer,

This head is more than churches or bibles or creeds. (lines 526-28)

*Shall I pray? Shall I venerate and be ceremonious?

I have pried through the strata and analyzed to a hair,

And counselled with doctors and calculated close, and found no sweeter fat than sticks to my own bones. (lines 398-400)

I'm going to come to an explanation of this apparently outrageous egotism momentarily, but let me first supply some examples of similar self-assurance from our president.

"I'm a very big person when it comes to the environment. I have received awards on the environment... I've won many environmental awards, by the way." (Lee)

After a recent mental health exam: "Let me tell you, those last ten questions are hard... There aren't a lot of people that can do that." (Chambers)

Trump tweeted that his record "would qualify as not smart, but genius... . and a very stable genius at that!" (Murray) 
"Sorry losers and haters, but my I.Q. is one of the highest -and you all know it! Please don't feel so stupid or insecure, it's not your fault." (O'Brien)

“I really believe, you don't know until you're tested, but I think I'd, I really believe I'd run in [to a school with an active shooter] even if I didn't have a weapon," Trump said. (Allen)

"I was always the best at what I did ..." ("Transcript")

"I was always the best athlete, people don’t know that." ("Transcript")

and even: "I am the world's greatest person.” (PressTV)

The he crucial difference is that Walt Whitman saw himself as a representative American, even a representative being; as a good Romantic, he believed that the poet was a poet because he could speak more eloquently truths that were truths for all men. So, for instance,

*In all people I see myself, none more and not one a barleycorn less,

And the good or bad I say of myself I say of them. (lines 401-402)

*These are the thoughts of all men in all ages and lands, they are not original with me,

If they are not yours as much as mine they are nothing or next to nothing,

If they are not the riddle and the untying of the riddle they are nothing,

If they are not just as close as they are distant they are nothing. (lines 353-357)

*All I mark as my own you shall offset it with your own,

Else it were time lost listening to me. (lines 391-92).

And the famous beginning, in which he celebrates himself, goes on to include the rest of us:

*I celebrate myself,

And what I assume you shall assume,

For every atom belonging to me as good belongs to you. (lines 1-3).

So Whitman brags on behalf of all mankind. His self-celebration is a celebration of the divinity of humanity, of which he positions himself as the representative and spokesman, the absorber and effuser, not the highest exemplar or the only instance. Donald Trump boasts, too, but without the philosophical or spiritual justification that underlies Whitman's "barbaric yawp." 


\section{Self-assurance and self-reliance}

Whitman was philosophically part of the movement we call American Transcendentalism. Its two most important voices are those of Ralph Waldo Emerson and Henry David Thoreau. And this movement, too, provided the basis for a powerful self-assertion rising, at least in the eyes of more skeptical observers, to self-absorption and a sort of romantic antinomianism.

One of the great sources for this doctrine is Emerson's essay of 1841 called "Self-Reliance." It is a powerful statement of the independence that Emerson sees arising from the confidence that one's inner spirit is a divine voice.

Trust thyself: every heart vibrates to that iron string. Accept the place the divine providence has found for you, the society of your contemporaries, the connection of events. Great men have always done so, and confided themselves childlike to the genius of their age, betraying their perception that the absolutely trustworthy was seated at their heart, working through their hands, predominating in all their being. (Emerson 146)

Emerson goes on to attempt to liberate the individual from two powerful forces that militate against self-reliance: conformity, or the world's opinion; and the fear of self-contradiction. As for worry about the world's judgment, he writes,

Whoso would be a man must be a nonconformist. He who would gather immortal palms must not be hindered by the name of goodness, but must explore if it be goodness. Nothing is at last sacred but the integrity of your own mind. Absolve you to yourself, and you shall have the suffrage of the world. (148)

As for consistency, his memorable dismissal reads "A foolish consistency is the hobgoblin of little minds, adored by little statesmen and philosophers and divines. With consistency a great soul has simply nothing to do" (152). Whitman likewise declares in "Song of Myself," "Do I contradict myself?/ Very well then... . I contradict myself;/ I am large... . I contain multitudes" (lines 1314-16). We should immediately recognize that Donald Trump, on this score at least, is a confirmed Emersonian, contradicting himself with wonderful regularity. He never worries about inconsistency.

Emerson's follower Thoreau was in agreement. This is the burden of his recommendation in Walden: "If a man does not keep pace with his companions, perhaps it is because he hears a different drummer. Let him step to the music which he hears, however measured or far away" (Thoreau 217). Thoreau is one of the founders of the political theory of civil disobedience and, hearing a different drummer, served time in jail for refusing to conform. In his essay on "Resistance to Civil Government," usually now referred to as "Civil Disobedience," he makes a statement that, on consideration, may strike some as worrying: "The only obligation which I have a right to assume is to do at any time what I think right" (Thoreau 227). 
What about democracy, the idea of majority rule? Thoreau: "any man more right than his neighbors constitutes a majority of one already" (234). Emerson: "Is not a man better than a town?" (Emerson 169).

The clear tendency of this doctrine is anti-democratic. Readers since the 1840s have noticed that a principle of action that reserves to oneself not just the freedom, but the obligation "to do at any time what I think right" has enormous potential for abuse. Thoreau, we may believe, when he acted according to his conscience, did what we would approve. He refused to pay taxes in protest of the Fugitive Slave Act and the war against Mexico. (Emerson rarely did anything controversial or adversarial.) But what if something else had been what he thought right? Would the same argument seem powerful if it turned out that John Wilkes Booth, who murdered President Abraham Lincoln, was a Thoreauvian, and recognized as his only obligation to do what he thought right - in this case an assassination?

As it happens, the same objection had been put to Emerson, and he explains how he responded.

I remember an answer which when quite young I was prompted to make to a valued adviser, who was wont to importune me with the dear old doctrines of the church. On my saying, What have I to do with the sacredness of traditions, if I live wholly from within? my friend suggested, - "But these impulses may be from below, not from above." I replied, "They do not seem to me to be such; but if I am the Devil's child, I will live then from the Devil." No law can be sacred to me but that of my nature. Good and bad are but names very readily transferable to that or this; the only right is what is after my constitution, the only wrong what is against it. (Emerson 148)

The application to the Trump era seems obvious. Like Thoreau, he is a majority of one. His indifference to traditional norms of behavior, to expectations of patience, judiciousness, courtesy and toleration, to the tradition - whether hypocritical or not - that candidates for President do not jeer at and ridicule their opponents, assigning them insulting nicknames, nor continue to abuse them after the election is over, his unwillingness to take advice, his threatening behavior, his uncontrolled tweeting - all these suggest that he lives wholly from within. His only right is to do what is after his constitution.

\section{Insularity and xenophobia}

There is a strong strain of insularity and xenophobia in the American story. The feeling that the settlers of what became the United States were a special group, singled out by God to be led out of their Egyptian captivity into a new Canaan, with its implication that the rest of the world is a corrupt environment to be escaped; the metaphor of the "new world" as opposed to the old world, largely meaning Europe; these are signs that the US is better off without having too much to do with anybody else. It helps that 
the country is so large and that it is protected on both coasts by thousands of miles of ocean. We are insular partly because we are a sort of island. The result in political terms has been a powerful strain of isolationism, the suggestion that we are self-sufficient, need not take too much interest in what other countries are doing and should leave them to their own mischief. We can see it in the refusal of the United States Congress to ratify the League of Nations Treaty after World War I (though it had been negotiated by our President Woodrow Wilson), the suspicion by some politicians that in both world wars we were being dragged into something that we would be better off ignoring, the steady drumbeat of opposition to the United Nations. President Bush's ambassador to the United Nations was a fierce opponent of the United Nations. President Trump has just named this man his new national security advisor.

His most potent campaign issue was opposition to immigration with the argument that foreign immigrants are bad for America. He has flirted with new regulations to decrease legal immigration, in addition to his various schemes to reduce illegal immigration from the south, through his famous wall. The idea that the US is a "melting pot," made up from many nationalities that enrich the fabric of our society - the knowledge that about half the "American" winners of Nobel prizes are born outside the United States - none of these carry any weight in a leader, and the populace he impresses, that are fearful of the foreign.

President Trump mistrusts most foreigners even if they are not trying to immigrate; he seems to believe that every foreign treaty is designed to embarrass or destroy the United States, that security arrangements which cost the American taxpayer money are scams by other NATO members or the Japanese. He suspects the good will and honesty of most foreigners who, it seems to him, are out to get America. He is even particularly suspicious of the good faith of America's traditional allies, all of whom, he believes, are exploiting the US while chuckling over how they can keep getting away with it.

Culturally the US is also parochial, in part because we export much of our culture and may feel no need to import any. In 2008 the permanent secretary of the Nobel Prize jury dismissed American literature as unimportant on the world stage, declaring, "The US is too isolated, too insular. They don't translate enough and don't really participate in the big dialogue of literature," Engdahl said (Goldenberg). "That ignorance is restraining." It is true that Americans read very little literature that is not Anglophone. About 3\% of the books published in the US are translations, and most of those are issued by small presses. Already in his essay on "The American Scholar," Emerson was insisting that "we have listened too long to the courtly muses of Europe" (62). Most Americans can only read foreign books if they have been translated, as learning foreign languages is not given priority. George W. Bush succeeded in making a campaign issue out of the fact that his opponent John Kerry speaks good French. It was widely reported that Bush did not possess a passport when he was elected president. This turns out to be untrue but had done almost no foreign traveling other than to Mexico (the country adjacent to Texas, where he lived). Only about $42 \%$ of Americans have a passport, and this has skyrocketed since 1990, when the figure was an almost unbelievable 4\% (McCarthy). 
Incidentally, Ralph Waldo Emerson was a traditional American in believing that "Traveling is a fool's paradise. Our first journeys discover to us the indifference of places" (Emerson 43). Donald Trump has in fact traveled widely and, for anything known to the contrary, may keep himself open to the varieties of experience to be gained in foreign lands and among foreign people. But he expects foreigners to stay where they are, not aspire to come to the United States or expect any help from us.

\section{American exceptionalism}

A number of the things I've said already relate to the phenomenon known as "American exceptionalism." That is the position that we are not like anybody else; that our country differs qualitatively from the rest of the world and has a unique role to play in world history; that our freedom, democracy, and other ideals set us apart from everyone else. References to the US as "the greatest nation in the world" are de rigeur in American politics, and even routine acclamation of what politicians often call "the greatest health care system in the world" are unaffected by the facts-facts for instance, that show our infant mortality rate is almost three times that of Finland and last among a list of "wealthy countries"-incidentally about $20 \%$ above the Polish figure. The superiority of American health care is an article of faith, a codicil of the American exceptionalism doctrine, and therefore impervious to correction.

This attitude goes back to the beginnings of European settlement of the American continent. During his travels across the young country in 1831 and 1832, the French statesman Alexis de Tocqueville concluded that "the situation of the Americans is... entirely exceptional, and it is to be believed that no [other] democratic people will ever be placed in it" (430). The Massachusetts "pilgrims"—-note the implication that they were on a religious mission - were convinced that they had been commissioned by God, as the modern counterparts of the ancient Israelites, to settle a virgin land and make a new society there, uncontaminated by and superior to the culture they had left behind. The feeling that God had given them the land helps to explain their indifference to the prior claims of the native Americans who were already living on it; the early settlers cared as little for those claims as the Israelites did for the priority of the Canaanites. One of the great sources for this view of American life comes from a sermon preached by John Winthrop in 1630, on a ship headed to Massachusetts:

Now the only way to avoid this shipwreck, and to provide for our posterity, is to follow the counsel of Micah, to do justly, to love mercy, to walk humbly with our God. For this end, we must be knit together, in this work, as one man. We must entertain each other in brotherly affection. We must be willing to abridge ourselves of our superfluities, for the supply of others' necessities. We must uphold a familiar commerce together in all meekness, gentleness, patience and liberality. We must delight in each other; make others' conditions our own; rejoice together, mourn together, labor and suffer together, always having before our eyes our 
commission and community in the work, as members of the same body. So shall we keep the unity of the spirit in the bond of peace. The Lord will be our God, and delight to dwell among us, as His own people, and will command a blessing upon us in all our ways, so that we shall see much more of His wisdom, power, goodness and truth, than formerly we have been acquainted with. We shall find that the God of Israel is among us, when ten of us shall be able to resist a thousand of our enemies; when He shall make us a praise and glory that men shall say of succeeding plantations, "may the Lord make it like that of New England." For we must consider that we shall be as a city upon a hill. The eyes of all people are upon us. So that if we shall deal falsely with our God in this work we have undertaken, and so cause Him to withdraw His present help from us, we shall be made a story and a by-word through the world.

This is a noble passage of American thought, with its call for mutual help, modesty, gentleness, patience and liberality, rather than competition, untrammelled individualism or self-aggrandizement. This is not the part that most people remember, though.

Ronald Reagan always liked the phrase "city upon a hill" - which he usually rendered for some reason as "shining city on a hill" - though his reading of it was naïve. Here is his version:

I've spoken of the shining city all my political life, but I don't know if I ever quite communicated what I saw when I said it. But in my mind it was a tall, proud city built on rocks stronger than oceans, windswept, God-blessed, and teeming with people of all kinds living in harmony and peace; a city with free ports that hummed with commerce and creativity. (Reagan)

Reagan missed Winthrop's warning; to him the US is a city on a hill because America is so wonderful - so exceptional - while Winthrop means that as a city upon a hill Americans must be extra careful since their sins and errors will be so obvious.

Mitt Romney claimed that Barack Obama didn't "have the same feeling about American exceptionalism that we do" (Beinart). Some have pointed out that Donald Trump also takes an eccentric position on American exceptionalism; while his slogan is "America First!" he also has an oddly apocalyptic view of his country's current situation, referring to what he considers its disastrous condition of "American carnage" and repeatedly insisting that foreigners are laughing at us. America should become again the greatest country in the world, he believes, implying that currently it is not; its problems, by his account, are so severe that he is the nation's only hope for salvation: "I alone can fix it" (Applebaum).

So the exceptionalism has been transferred from the country to the individual. The nation may be exceptionally troubled, but fortunately the president is exceptionally puissant. 


\section{Conclusion}

The American tradition from which Donald Trump emerges, or diverges, has as one of its central themes some confusion about equality, which might be oversimplified in the old boast, "I'm as good as anybody—no, better." As Tocqueville had already noticed in the $1830 \mathrm{~s}$,

Democratic institutions awaken and flatter the passion for equality without ever being able to satisfy it entirely. Every day this complete equality eludes the hands of the people at the moment when they believe they have seized it.... All that surpasses them, in whatever place, then appears to them as an obstacle to their desires, and there is no superiority so legitimate that the sight of it does not tire their eyes. (189)

That irksomeness, that reluctance to recognize the superiority of anyone else, that ethic of egalitarianism underwriting self-reliance, disdain for expertise, and boastfulness, helps to explain much about American life and much about the presidency of Donald J. Trump.

\section{References}

Allen, Nick. "Donald Trump says he would have 'run in' to Florida shooting without a weapon." Daily Telegraph (26 February 2018). Online: downloaded 8 June 2018. Applebaum, Yoni. "I Alone Can Fix It." The Atlantic (21 July 2016). Online: downloaded 9 June 2018.

Beinart, Peter. "The End of American Exceptionalism.” The Atlantic (3 February 2024). Online: downloaded 9 June 2018.

Blake, Aaron. "19 things Donald Trump knows better than anyone else, according to Donald Trump." The Washington Post (4 October 2016). Online: downloaded 8 June 2018.

Boorstein, Michelle. “Trump on God: 'Hopefully I won't have to be asking for much forgiveness.'"The Washington Post (June 8, 2016). Online, downloaded 8 June 2018.

Chambers, Francesca. " “'Those last ten questions are hard': Trump brags about 30-for-30 performance on simple cognitive exam." Daily Mail (2 February 2018). Online: downloaded 8 June 2018.

Emerson, Ralph Waldo. 1940. The Complete Essays and Other Writings of Ralph Waldo Emerson. Ed. Brooks Atkinson. New York: Modern Library.

Fee, Christopher R. and Jeffrey B. Webb. 2016. American Myths, Legends, and Tall Tales: An Encyclopedia of American Folklore (Volume I). Santa Barbara, CA: ABC-CLIO.

Gass, Nick. "Trump: 'The Experts Are Terrible."” Politico (4 April 2016). Online: download 8 June 2018.

Gibson, Lydialyle. "The Mirage of Knowledge: Tom Nichols dissects the dangerous antipathy to expertise." Harvard Magazine (March-April 2018). Online: downloaded 9 June 2018. 
Goldenberg, Suzanne. "No Nobel prizes for American writers: they're too parochial." The Guardian (1 October 2008). Online: downloaded 9 June 2018.

Hains, Tim. "Trump: I Own A Store In Manhattan Worth More Than Mitt Romney." Real Clear Politics (3 March 2016). Online: downloaded 8 June 2018.

Hawthorne, Nathaniel. 1966. "The Maypole of Merry Mount." Selected Short Stories of Nathaniel Hawthorne. Ed. Alfred Kazin. New York: Fawcett, p. 34-44.

Johnson, Jenna. "Donald Trump begs Iowans not to believe Ben Carson: 'Don't be fools, okay?"” The Washington Post (13 November 2015). Online: download 8 June 2018.

Lee, Michelle Ye He. "Trump's unsupported claim he has 'received awards on the environment." The Washington Post (24 January 2017). Online: downloaded 8 June 2018.

Lemire, Jonathan. "Trump makes puzzling claim about Andrew Jackson, Civil War." The Chicago Tribune (May 1, 2017). Online: downloaded 8 June 2018.

McCarthy, Niall. 'The Share Of Americans Holding A Passport Has Increased Dramatically In Recent Years.' Forbes (11 January 2018). Online: downloaded 9 June 2018.

Milbank, Dana. “The gospel according to the Donald." The Washington Post (20 January 2016). Online: downloaded 8 June 2018.

Murray, James. “'I'm a stable genius' says defiant Trump.” Sunday Express (7 January 2018). Online: downloaded 8 June 2018.

Nichols, Tom. "Trump is delivering what he promised: A government with no experts." The Washington Post (8 March 2018). Online: downloaded 9 June 2018.

O'Brien, Timothy L. "Trump Has the Highest IQ. He Says So Himself." Bloomberg News (10 October 2017). Online: downloaded 8 June 2018.

PressTV. “'I am the world’s greatest person,' Trump said in leaked transcript.” (4 August 2017). Online: download 8 June 2018.

Reagan, Ronald. "Farewell Address to the Nation." The American Presidency Project. Online: downloaded 9 June 2018.

Thoreau, Henry D. 1992. Walden and Resistance to Civil Government. New York: Norton.

Toqueville, Alexis de. 2000. Democracy in America. Trans. and Ed. Harvey C. Mansfield and Delba Winthrop. Chicago: U of Chicago P.

"Transcript of Donald Trump Interview With The Wall Street Journal." Wall Street Journal (14 January 2018). Online: downloaded 8 June 2018.

Trump, Donald J. "Nobody" (15 June 2016). Viewable on youtube.com at https://www.youtube. $\mathrm{com} /$ watch? $\mathrm{v}=\mathrm{h} 7 \mathrm{JYuVEAqEQ}$

"Trump explains why he feels the primary process is 'unfair." Fox News (13 April 2016). Online: downloaded 8 June 2018.

"Trump says his tax rate is 'none of your business.' PBS News Hour (13 May 2016). Online: downloaded 8 June 2018.

Whitman, Walt. 1960. Leaves of Grass: The First (1855) Edition. Ed. Malcolm Cowley. New York: Viking Press.

Winthrop, John. "A Model of Christian Charity." The Winthrop Society. Online: downloaded 12 June 2018.

Wootson, Cleve R., Jr. "Trump implied Frederick Douglass was alive. The abolitionist's family offered a 'history lesson'.” The Washington Post (Feb 2, 2017). Online: downloaded 8 June 2018. 